\title{
Potentiometric Determination of L-Ascorbic Acid in Pharmaceutical Samples by FIA Using a Modified Tubular Electrode
}

\author{
Julio Cesar B. Fernandes ${ }^{\mathrm{a}}$, Laércio Rover Jr. ${ }^{\mathrm{a}}$, Lauro T. Kubota ${ }^{\mathrm{a}^{*}}$ and Graciliano de Oliveira Neto \\ anstituto de Química, Universidade Estadual de Campinas, CP 6154, 13083-970, Campinas - SP, Brazil \\ ${ }^{\mathrm{b}}$ Faculdade de Ciências Farmacêuticas, Universidade São Francisco, Bragança Paulista - SP, Brazil
}

\begin{abstract}
Um sistema de análise por injeção em fluxo usando um eletrodo tubular baseado nas propriedades redox de íons cobre (II) oclusos em membrana de EVA foi desenvolvido para determinação de ácido L-ascórbico.A matriz de polietileno-co-vinil acetato (EVA $40 \% \mathrm{~m} / \mathrm{m}$ ) foi dopada com íons cobre (II) e dispersa na superfície de um eletrodo tubular de grafite/epóxi. O eletrodo mostrou resposta super-Nernstiana para ácido L-ascórbico na faixa de concentração entre $10^{-3}-10^{-1} \mathrm{~mol} \mathrm{~L}^{-1}$ com um limite de detecção de $8,5 \times 10^{-4} \mathrm{~mol} \mathrm{~L}^{-1}$, quando $0,1 \mathrm{~mol} \mathrm{~L}^{-1}$ de tampão $\mathrm{KH}_{2} \mathrm{PO}_{4}$ misturado com $0,1 \mathrm{~mol} \mathrm{~L}-1$ de peróxido de hidrogênio em $\mathrm{pH}$ 5,0 foi empregado como solução carregadora. O sistema FIA-potenciométrico permite uma freqüencia analítica de 120 amostras por hora com uma precisão de 3,6 \%. Os resultados obtidos na determinação de ácido Lascórbico em amostras farmacêuticas, sem qualquer tratamento prévio, pelo método proposto foram similares a aqueles obtidos pelo método da Farmacopéia Britânica.
\end{abstract}

A flow injection system using a tubular electrode based on the redox properties of copper (II) ions occluded in EVA membrane was developed for L-ascorbic acid determination. The polyethylene-co-vinyl acetate (EVA $40 \% \mathrm{~m} / \mathrm{m}$ ) matrix was doped with copper (II) ions and dispersed on the surface of a graphite/epoxy tubular electrode. The electrode showed a super-Nernstian response for $\mathrm{L}$-ascorbic acid concentration between $10^{-3}$ and $10^{-1} \mathrm{~mol} \mathrm{~L}^{-1}$ with a detection limit of $8.5 \times 10^{-4} \mathrm{~mol} \mathrm{~L}^{-1}$, when $0.1 \mathrm{~mol} \mathrm{~L}^{-1} \mathrm{KH}_{2} \mathrm{PO}_{4}$ buffer mixed with $0.1 \mathrm{~mol} \mathrm{~L}^{-1}$ hydrogen peroxide at pH 5.0 was employed as carrier. The Potentiometric-FIA system allows an analytical frequency of 120 samples per hour with a precision of $3.6 \%$. The results obtained for ascorbic acid determination in pharmaceutical samples, without any previous treatment, were similar to those obtained by the British Pharmacopoeia method.

Keywords: L-ascorbic acid determination, tubular electrode, FIA, pharmaceutical samples

\section{Introduction}

L-ascorbic acid is a very important vitamin for human beings, as it participates in various metabolic processes. Its deficiency causes scurvy, which provokes degeneration in blood vessel, teeth, bone and difficulty in cicatrization 1-3. The stability of aqueous solutions of L-ascorbic acid is dependent on the temperature, ultraviolet light, oxygen pressure, $\mathrm{pH}$, and catalysts such as copper (II) ions ${ }^{4-7}$.

The development of a potentiometric biosensor for Lascorbic acid based on ascorbate oxidase obtained from the cucumber peel showed that the potential development of the electrode surface was probably due to $\mathrm{Cu}^{2+}$ ions present in the molecular structure of the enzyme 8 . Recent work us-

*e-mail: kubota@iqm.unicamp.br ing cupric ions (copper sulfate) occluded directly into a membrane in substitution of the ascorbate oxidase corroborated this idea, showing response to the L-ascorbic acid and some advantages in relation to the biosensor such as better sensitivity and stability ${ }^{9}$. Moreover, it is less expensive. In both cases, the potential change in the electrode was caused by the charge density variation due to the reduction of $\mathrm{Cu}^{2+}$ to $\mathrm{Cu}^{1+}$ by the monoascorbate ion. The electrode is regenerated by $\mathrm{O}_{2}$ which reoxidizes the $\mathrm{Cu}^{1+}$ to $\mathrm{Cu}^{2+}$. However, the analysis time with the electrode in the steady state was long, and depended on the quantity of copper (II) ions in the membrane and the oxygen pressure. In first instance, an excess of copper (II) ions in the membrane affected the potential due to leaching from the membrane to the solution. On the other hand, the neccessity of electrode regeneration with oxygen causes an increase in the time required to reach 
a new equilibrium. Thus, the analysis time was about 10 to 15 min resulting in a maximum analytical frequency of 6 samples per hour. Flow injection analysis is a kinetic technique that may overcome these problems, minimizing the leaching out effect in the system and allowing quick regeneration of the electrode. This work describes the preparation of a tubular sensor based on cupric ions occluded into EVA membrane, as well as the evaluation of the sensor performance and optimization of the FIA system, for application in the determination of vitamin $\mathrm{C}$ in pharmaceutical samples.

\section{Experimental}

\section{Chemicals and samples}

L-ascorbic acid, potassium dihydrogenophosphate, hydrogen peroxide and copper (II) sulfate were purchased from Merck (Darmstadt - Germany). The poly(ethyleneco-vinyl acetate), EVA $40 \%(\mathrm{~m} / \mathrm{m})$ copolymer was acquired from Aldrich (Milwaukee - USA). The pharmaceutical samples were purchased at a local drugstore.

\section{Procedures}

Preparation of the potentiometric sensitive membrane for L-ascorbic acid

A saturated solution of copper (II) sulfate is prepared by dissolving about $0.5 \mathrm{~g}$ in $500 \mathrm{~mL}$ of deionized water. Then, $500 \mathrm{~mL}$ of EVA solution $(0.25 \mathrm{~g}$ in $10 \mathrm{~mL}$ of tetrahydrofuran - THF) is added to $100 \mathrm{~mL}$ of the copper (II) solution and the resulting mixture is dropped into a tubular graphite/epoxy electrode (Figure 1). The membrane was left to dry for $30 \mathrm{~min}$ and the electrode was stored at room temperature.

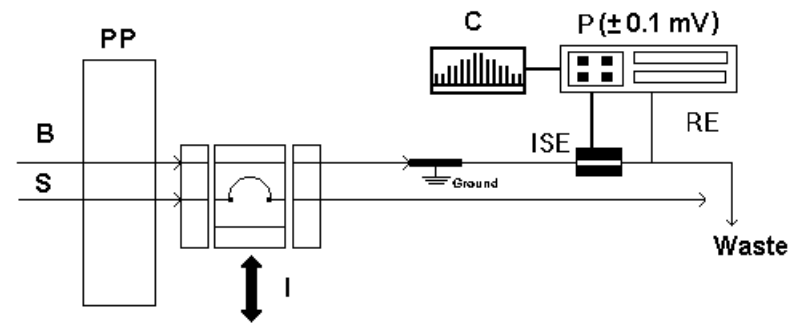

Figure 1. Scheme of the cell and tubular electrode used in flow system.

\section{Potentiometric-FIA system}

Figure 2 shows the schematic diagram of the employed Potentiometric-FIA system. The carrier solution (B - 0.1 mol L-1 phosphate buffer at $\mathrm{pH} 5.0$ mixed with $0.1 \mathrm{~mol}$ $\left.\mathrm{L}^{-1} \mathrm{H}_{2} \mathrm{O}_{2}\right)$ was aspirated through Tygon ${ }^{\circledR}$ tube $(1.42 \mathrm{~mm}$ i.d.) by the peristaltic pump (PP) Ismatec (IPC- 8 model) at a constant flow-rate of $2.2 \mathrm{~mL} \mathrm{~min}^{-1}$ to the tubular electrode (ISE). The potentials, developed by the ascorbate on the ion selective electrode were measured with a $\mathrm{pH} /$ Ion Analyser ( $\mathrm{P}$ ) from Corning (350 model), using an $\mathrm{Ag} / \mathrm{AgCl}$ wire (RE) as reference, coupled to a microcomputer (C) for data acquisition. All measurements were carried out at room temperature. A manual homemade injector (I) was used to add $50 \mu \mathrm{L}$ of the sample and standard solutions ( $\mathrm{S}$ ) in the carrier line. The peak height was utilized to correlate the signal with the concentration of standards and samples. The standard method of British Pharmacopoeia 10 for ascorbic acid determination was employed to compare the results obtained with the proposed system.

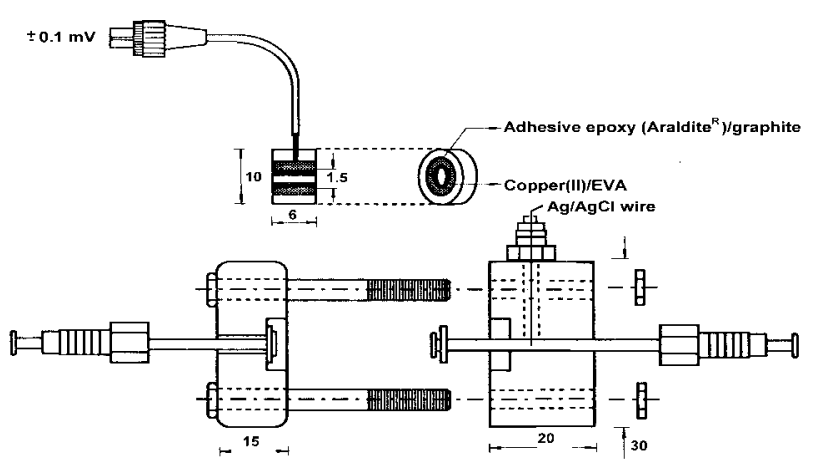

Figure 2. Flow injection manifold for L-ascorbic acid determination in pharmaceutical samples by potentiometric detection using tubular electrode.

The L-ascorbic acid standard solutions were freshly prepared with deionized water in the concentrations between $1 \times 10^{-4}$ and $1 \times 10^{-1} \mathrm{~mol} \mathrm{~L}^{-1}(\mathrm{pH}<3)$. Some interferents were studied by the matched-potential method, which is recommended by the International Union of Pure and Applied Chemistry (IUPAC) to overcome difficulty in the obtainment of accurate selectivity coefficients when ions of unequal charges are involved or if the interfering ions do not follow the Nicolsky-Eisenman equation. In this method, the Kpot is defined as the activity (concentration) ratio of the primary ion and the interfering ion, which gives the same potential change in a reference solution 11,12. The Kpot can be calculated by the equation:

$K_{\mathrm{A}, \mathrm{B}}^{\mathrm{pot}}=\frac{a_{A}-a_{A}}{a_{B}}$

where, $\mathrm{a}_{A}$ is initial background activity of primary ion (A); $a_{B}$ is activity of interfering ion that gives the same potential that a given activity of the primary ion $\left(\mathrm{a}_{A}\right.$ ') previously established. 


\section{Results and Discussions}

\section{Optimization of the FIA system}

Effect of $p \mathrm{H}$, ionic strength, $\mathrm{H}_{2} \mathrm{O}_{2}$ concentration and FIA system parameters

A previous study 9 showed that the electrode based on copper (II) ions occluded in EVA exhibits a response for ascorbate in the $\mathrm{pH}$ range between 3.5 and 8.0 and an ionic strength between 0.1 and $1 \mathrm{~mol} \mathrm{~L}^{-1}$ had no significant effect on the electrode response. However, kinetic studies of the autoxidation of L-ascorbic acid catalyzed by cupric ions showed that the rate constant decreases at lower solution $\mathrm{pH}$; being zero at $\mathrm{pH}$ below 2.04,5. On the other hand, it has been suggested that for maximum stability, the ascorbic acid solutions should be buffered at a pH less than 5.413. Based on these considerations a $0.1 \mathrm{~mol} \mathrm{~L}^{-1}$ phosphate buffer at pH 5.0 as carrier was employed. One problem in the optimization of the Potentiometric-FIA system was the regeneration of the copper (II) ions on the electrode. A carrier line containing only buffer produced a signal with a long regeneration time, as can be seen in Figure 3a (A). This is explained by the small quantity of oxygen dissolved in the carrier line. Thus, the time required to regenerate the electrode is long. Therefore, to improve the electroderegeneration time without a significant decrease in thesignal, a stronger oxidizer was tested; hydrogen peroxide was mixed with the buffer. The best ratio between signal and regeneration time was verified for a hydrogen peroxide concentration of $0.1 \mathrm{~mol} \mathrm{~L}^{-1}$ as shown in Figure 3. An increase in the hydrogen peroxide concentration above $0.1 \mathrm{~mol} \mathrm{~L}^{-1}$, results in a diminished regeneration time but also proportionally decreases the signal. Therefore, the tubular electrode proposed for L-ascorbic acid based on copper (II) ions incorporated in EVA works at $\mathrm{pH} 5.0$, according to the equations 14,15 :

monoascorbate monodehydroascorbate $+\mathrm{H}^{+}$

$+\mathrm{e}^{-} ; \mathrm{E}^{0}=+127 \mathrm{mV}$

$\mathrm{Cu}^{2+}+\mathrm{e}^{-} \mathrm{Cu}^{1+} ; \mathrm{E}^{0}=+158 \mathrm{mV}$

$\mathrm{H}_{2} \mathrm{O}_{2}+2 \mathrm{H}^{+}+2 \mathrm{e}^{-} \rightleftharpoons 2 \mathrm{H}_{2} \mathrm{O} ; \mathrm{E}^{0}=+1770 \mathrm{mV}$

The potential $\mathrm{E}_{\mathrm{Cu}^{2+}} \mathrm{Cu}^{1+}$ in the EVA membrane, which is monitored by the graphite/epoxy electrode, is given by the Nernst equation:

$E_{\mathrm{Cu}^{2+} / \mathrm{Cu}}{ }^{l+}=E_{\mathrm{Cu}^{2+} / \mathrm{Cu}}^{\mathrm{l+}}+\frac{R T}{n F} \ln \frac{\mathrm{Cu}^{2+}}{\mathrm{Cu}^{\mathrm{l+}}}$

At a constant concentration of $\mathrm{H}_{2} \mathrm{O}_{2}$ and copper (II) (a)

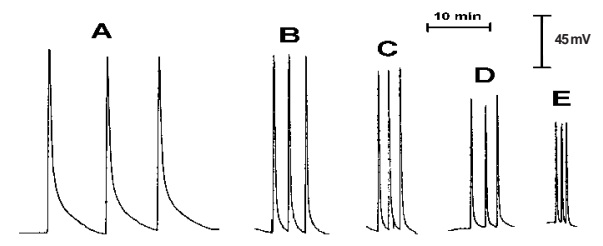

(b)

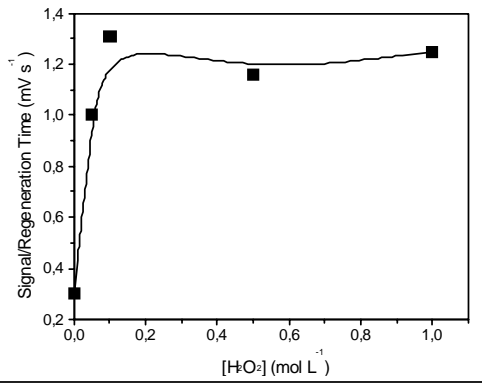

Figure 3. Effect of the hydrogen peroxide concentration in the signal and regeneration time ratio of electrode, obtained for injection of $50 \mathrm{~mL}$ of $0.1 \mathrm{~mol} \mathrm{~L}^{-1} \mathrm{~L}$-ascorbic acid. (a) Signal obtained for different $\mathrm{H}_{2} \mathrm{O}_{2}$ concentrations, mol L-1: A. without; B. 0.05; C. 0.1 ; D. 0.5; E. 1.0. (b) Graphic representation.

ions the potential of the electrode can be represented as:

$E_{\text {monoascorbate }}=E^{0}+\frac{R T}{F}$ lu[monoascorbate]

where, Eo is $E_{\mathrm{Cu}^{2+} / \mathrm{Cu}^{+1}}=E_{\text {monoascorbate }}^{0}+$ constant

The influence of sample volume and flow-rate on the potentiometric signal produced by the L-ascorbic acid is shown in Figure 4. The signal increases with the sample volume and tends to be a constant for an injected volume greater than $100 \mathrm{~mL}$, indicating saturation of the copper (II) ions on the sensor surface. The flow-rate causes a significant influence in the signal increasing it until $2.2 \mathrm{~mL}$ $\min ^{-1}$ and decreasing considerably at greats flow-rates. This occurs due to a reduced oxidation velocity of the monoascorbate ion catalyzed by the copper (II) ions. The best conditions for good sensitivity and proportioning a high analytical frequency were $2.2 \mathrm{ml} \mathrm{min}^{-1}$ flow-rate and sample volume of $50 \mathrm{~mL}$. The response time and the regeneration time of the electrode, under these conditions, were $4.3 \mathrm{~s}$ and $15.0 \mathrm{~s}$, respectively.

\section{Analytical performance of the system}

Figure 5 shows the signals of the standard used solutions to obtain the calibration curve for L-ascorbic acid with the proposed potentiometric-FIA system. The sensor presented super-Nernstian behavior between $10^{-3}$ and $10^{-1}$ mol L-1 concentration range for L-ascorbic acid with 


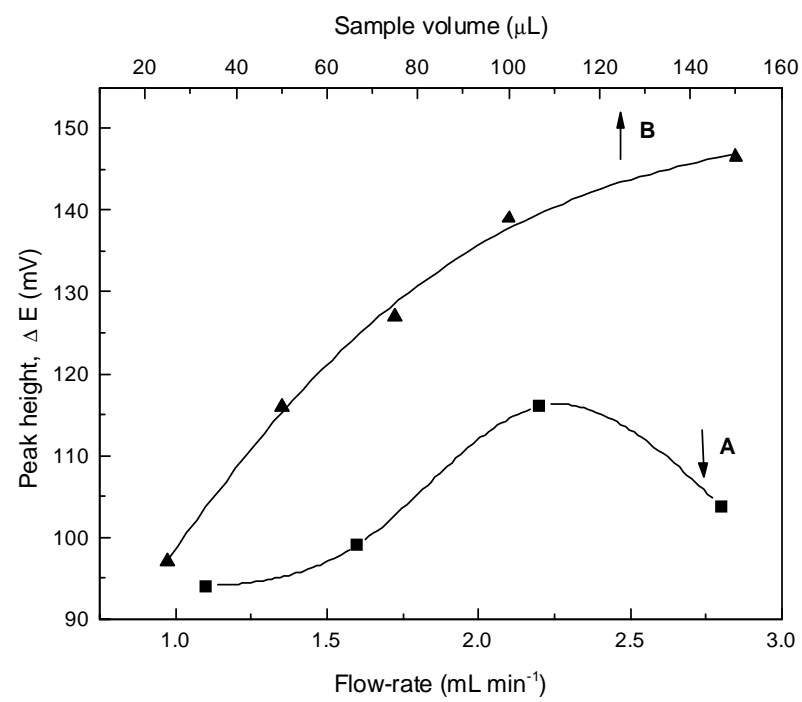

Figure 4. Influence of the sample volume and flow-rate in the signal of the proposed Potentiometric-FIA system for L-ascorbic acid concentration, $3 \times 10^{-2} \mathrm{~mol} \mathrm{~L}^{-1}$. Effect of the flow-rate $(\mathbf{A})$ and injected sample volume (B) on the potentiometric signal. Conditions: A Sample volume, $50 \mathrm{~mL}$ and B Flow-rate, $2.2 \mathrm{ml} \mathrm{min}^{-1}$.

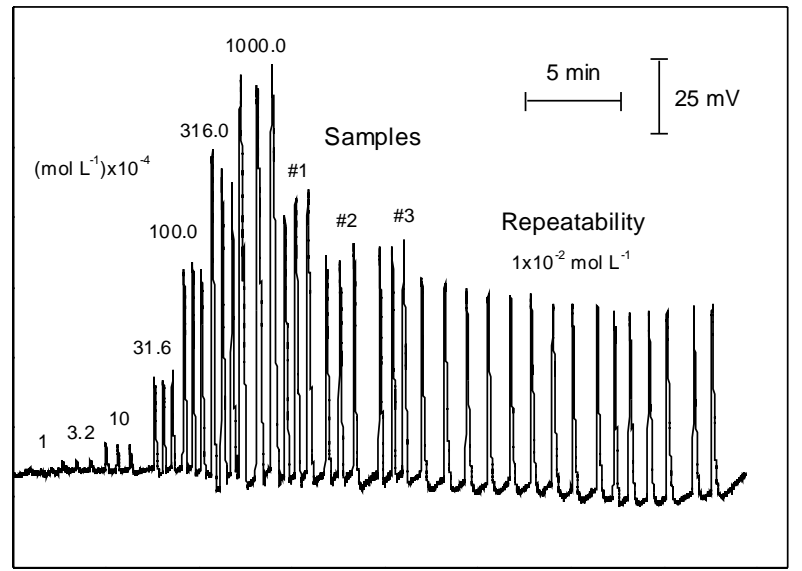

Figure 5. Diagram showing a typical signal obtained with the proposed FIA system using a potentiometric sensor based on copper (II) ions occluded in EVA membrane. It shows the signals for injections of standards, samples and repeatability.

a detection limit of $8.5 \times 10^{-4} \mathrm{~mol} \mathrm{~L}^{-1}$ in the optimized conditions. This super-Nernstian behavior can be explained by a memory effect due to adsorption of L-ascorbic acid as a result of the high concentration of copper (II) ions in the membrane. The equation that describes the analytical performance of the sensor is given by:

$\Delta E=-(2126)+(693) p[$ ascorbic acid $]$

The correlation coefficient (r) was 0.997 for $\mathrm{N}=5$.

The system allows an analytical frequency of 120 samples per hour with a precision of $3.6 \%$ (relative standard deviation for repeatability of 15 injections). The
Table 1. Potentiometric selectivity coefficients for the monoascorbate sensor estimated by the matched-potential method ${ }^{11}$ at $\mathrm{pH}$ 7.0.

\begin{tabular}{ll}
\hline Interfering & $\mathrm{K}_{\mathrm{A}, \mathrm{B}}$ pot* $^{*}$ \\
\hline Hydroquinone & 6.0 \\
Dopamine & 4.2 \\
Catechol & 1.4 \\
L-Dopa & 0.91 \\
4-Nitrophenol & 0.10 \\
3-Nitrophenol & 0.10 \\
Tyrosine & 0.093 \\
2-Nitrophenol & 0.091 \\
Phenol & 0.090 \\
Resorcinol & 0.090 \\
\hline
\end{tabular}

system was tested during six months without any change in the signal being observed. A previous study of several interferents ${ }^{9}$ demonstrated that the sensor based on EVA doped with copper (II) ions was about 250 times more sensitive for L-ascorbic acid than iodide, the main interfering ion. The possible interferents to the proposed electrode are catechol and its derivatives, because these substances are also oxidized by oxygen in the presence of copper (II) 16 . Table 1 shows the influence of some phenolic compounds on the response of the sensor. The electrode showed a response for 1,4- dihydroxybenzene (hydroquinone), 3 hydroxytyramine (dopamine), 1,2-dihydroxybenzene (catechol) and 3-(3,4-dihydroxyphenyl)-L-alanine (L-dopa). In the hydroquinone and dopamine cases, the electrode responds about six and four times greats for these substances than L-ascorbic acid, respectively. However, these compounds are not present in pharmaceutical formulations containing L-ascorbic acid and thus are not a serious problem. Moreover, Balla et al.16 suggested that the pH-dependence of the kinetic data in the oxidation of catechol catalyzed by copper (II) involves the monoprotonated species rather than undissociated species with a chain-propagation step. The $\mathrm{pK}^{17}$ of the hydroxyl groups in the hydroquinone (10.4), dopamine (10.4 and 13.1), catechol (9.3 and 13.0) and L-dopa (10.0 and 11.8) suggests that at a pH below 4.0 these substances are in the totally undissociated form and therefore the electrode does not respond to them. Tests with dopamine at $\mathrm{pH} 4.0$ confirm this hypothesis. The applicability of the proposed sensor is verified by the results listed on Table 2 for vitamin $\mathrm{C}$ determination in pharmaceutical samples. The analyzed drugs contain several compounds in their formulations, each as sweeteners, salts and preservatives, but no significant interference was observed. The result for vitamin C determination in these samples gave good agreement to the Spectrophotometric 18 and British Pharmacopoeia methods ${ }^{10}$, that showing a good applicability of the FIA method for ascorbic acid determination in real samples. 
Table 2. Results obtained in the Vitamin C determination in pharmaceutical samples with the proposed potentiometric-FIA system.

\begin{tabular}{cccrr}
\hline Samples & Nominal value & Spectrophotometric ${ }^{18}$ & FIA & British Pharmacopoeia $^{10}$ \\
\hline$\# 1$ & $1 \mathrm{~g} /$ Tablet & $1.04( \pm 0.02)^{*}$ & $1.02( \pm 0.05)^{*}$ & $1.032( \pm 0.004)^{*}$ \\
$\# 2$ & $1 \mathrm{~g} / 10 \mathrm{~g}$ of drug & $1.07( \pm 0.02)$ & $1.10( \pm 0.10)$ & $1.01( \pm 0.01)$ \\
$\# 3$ & $0.24 \mathrm{~g} /$ Tablet & $0.240( \pm 0.001)$ & $0.23( \pm 0.01)$ & $0.252( \pm 0.002)$ \\
\hline
\end{tabular}

Containing: \#1 $1 \mathrm{~g}$ of sucrose; \#2 $3.8 \mathrm{~g}$ of sucrose and $5 \mathrm{~g}$ of glucose; \#3 $0.40 \mathrm{~g}$ of Acetylsalicylic acid;

* Standard deviation of three determinations.

\section{Conclusions}

Few FIA systems for L-ascorbic determination are described in the literature. Those described are associated with amperometric and spectrophotometric detection 18-21 differential measurements or previous sample treatment on line to eliminate interference. To our knowledge, the application of FIA coupled to a potentiometric sensor for Lascorbic determination that combines the selectivity of the sensor with the speed of the technique has not been reported. The Potentiometric-FIA system proposed for Lascorbic acid determination, in pharmaceutical samples, shows simplicity, rapidity and efficiency, in relation to the others methods. The FIA system permitted the solution of some problems that the potentiometric electrode based on an EVA membrane doped with copper (II) ions presented and improved the response and regeneration time of the electrode. This methodology can be applied with good precision to the quality control of vitamin $\mathrm{C}$ in pharmaceutical samples.

\section{Acknowledgements}

The authors thank FAPESP, PRONEX, PADCT and CNPq for financial support. JCBF is indebted to FAPESP and LRJr to CAPES for fellowships.

\section{References}

1. Voet, D.; Voet, J. G. Biochemistry, Wiley, 1990, p. 160F, 251F, 536F.

2. Tolbert, B. M.; Ward, J. B. Ascorbic Acid, Chemistry, Metabolism and Uses, in: P.A. Seib, B. M. Tolbert (Eds.), Advances in Chemistry 200, American Chemical Society, Washington, DC, 1982.

3. Clemetson, C. A. B. Vitamin C, CRC Press, Boca Raton, FL, 1989.
4. Khan, M. M. T.; Martell, A. E. J. Am. Chem. Soc. 1967, 89, 4176.

5. Ogata, Y.; Kosugi, Y.; Morimoto, T. Tetrahedron 1968, 24, 4057.

6. Ogata, Y.; Kosugi, Y. Tetrahedron 1969, 25, 1055.

7. Baker, W. L.; Lowe, T. Analyst 1985, 110, 1189.

8. Fernandes, J. C. B.; de Oliveira Neto, G.; Kubota, L. T. Anal. Chim. Acta 1999, 385, 3.

9. Fernandes, J. C. B.; de Oliveira Neto, G.; Kubota, L. T. Electroanalysis 1999, 11, 475.

10. British Pharmacopoeia, HMSO, London, 1980, $733 \mathrm{pp}$.

11. Umezawa, Y.; Umezawa, K.; Sato, H. Pure Appl. Chem. 1995, 67, 507.

12. Gadzekpo, V. P. Y.; Christian, G. D. Anal. Chim. Acta 1984, 164, 279.

13. Reynolds, J. E. F.; Prascal, A. B. Martindale, the Extra Pharmacopeia, 28th ed., Pharmaceutical Press, London, 1982, p. 1653.

14. Fluka Chemika-Ciochemika Analytika Catalog, Fluka Chemie AG Industriestrasse 25 CH-9471 Buchs, Switzerland, 1995/96, p. 156

15. Bard, A. J.; Faulkner, L. R. Eletrochemical Methods Fundamental andApplications, Vol. II, JohnWiley \& Sons, USA, 1980.

16. Balla, J.; Kiss T.; Jameson, R. F. Inorg. Chem. 1992 , $31,58$.

17. Weast, R. C. Handbook of Chemistry and Physics, 78th ed., Boca Raton, CRC Press, INC, 1998.

18. Fernandes, J. C. B.; de Oliveira Neto, G.; Kubota, L. T. Anal. Chim. Acta 1998, 366, 11.

19. Greenway, G. M.; Ongomo, P. Analyst 1990, 115, 1297.

20. Jain, A.; Chaurasia, A.; Verma, K. K. Talanta 1995, 6,779 .

21. Verma, K. K.; Jain, A.; Chaurasia, A. Analyst 1991, 116,641 .

Received: March 16, 1999

FAPESP helped in meeting the publication costs of this article. 